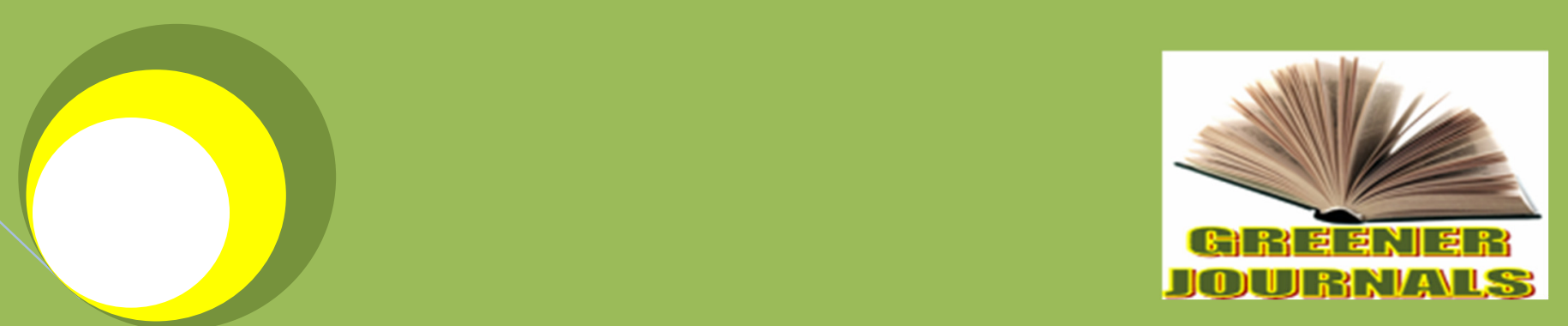

Greener.Journal of Medical Sciences

ISSN: 2276-7797

ICV: $\mathbf{5 . 9 8}$

Submitted: $10 / 03 / 2017$

Accepted: 20/03/2017

Published: 30/07/2017

DOI: http://doi.org/10.15580/GJMS.2017.3.052117065

The effects of Cyperus

esculentus (Tiger nut) on

Haematological and

Biochemical Profile of Male

Hypercholesteremic Subjects in

Uli, Anambra State Nigeria

By

Oguwike F.N.

Eluke B.C.

Eze R.I.

Asika C.M.

Nwosu P.N.

Nwafor C.

Onumonu C. 
Research Article (DOI: http://doi.org/10.15580/GJMS.2017.4.061717075)

\title{
The effects of Cyperus esculentus (Tiger nut) on Haematological and Biochemical Profile of Male Hypercholesteremic Subjects in Uli, Anambra State Nigeria
}

\author{
Oguwike F.N. ${ }^{\star 1}$, Eluke B.C. ${ }^{2}$, Eze R.I. ${ }^{3}$, Asika C.M. ${ }^{4}$, Nwosu P.N. ${ }^{1}$, \\ Nwafor C. ${ }^{1}$, Onumonu C. ${ }^{1}$
}

\author{
${ }^{1}$ Department of Physiology, Faculty of Basic Medical Sciences. Chukwuemeka Odumegwu Ojukwu University Uli \\ Campus, Anambra state. \\ 2Department of Medical Lab. Sciences, Faculty of Health Sciences University of Nigeria Enugu Campus. \\ ${ }^{3}$ Department of Medical Lab. Sciences, Madonna University Elele Rivers State. \\ ${ }^{4}$ Department of Pharmacology, Ebonyi state University Ebonyi state.
}

*Corresponding Author's Email: foguwike@ gmail .com; Phone: 08037791363

\begin{abstract}
Cholesterol, though needful in the body, when it is excess in the body can build up in the coronary arteries and increase the risk of heart diseases. This provoked our enthusiasm to research on plant material or nut that when eaten can knock down high cholesterol in the body.

Tiger nut is one of such nuts. It is called "Aya" in Hausa "Ofio" in Yoruba, and "Akiausa" in Igbo. It contains high level of oleic acid which has the potentials to exert a negative effect on cholesterol present in the human blood. This encouraged the study using Tiger nut. 80 persons consisting of both male and female adults diagnosed of high cholesterol were randomly selected for this study.

They were placed on the ingestion of tiger nut along with their normal diets for 14days. At the end of 28 days, blood samples were collected from them before and after the ingestion of tiger nut for biochemical and haematological analysis.

Results of the analysis indicate that tiger nut did not have any effect on the haemoglobin concentrations, packed cell volume, white blood cell count, platelet count and liver function profiles,but it drastically reduced the cholesterol level of the subjects. It could be deduced from the study that tiger nut contains some active principles that can lower cholesterol levels in the subjects.
\end{abstract}

Keywords: cholesterol, Tiger nut, venous blood, Haemoglobin, Packed cell volume, Platelets, White blood cell count.

\section{INTRODUCTION}

Tiger nut are not actually nuts but tubers found in the root of sedge plant. They are edible tubers with a sweet nutty flavor (Akuoma et al, 2000). They are quite hard and are generally soaked in water before consumption. Tiger nut has several varieties (black, brown and yellow). Among all these, the yellow variety is preferred over others because of its inherent properties such as large size, attractive color, and fresher nature. It also yields more milk. Upon extraction, it contains lower fat and higher protein and less anti-nutritional factors especially polyphenol.

Cholesterol is found in every cell of the body and has important natural function. It is manufactured by the body and can also be taken in from food. It is waxy and fat-like in appearance. Cholesterol is oil based and so does not mix with the blood, which is water based. It is therefore carried around the body in the blood by lipoproteins. Although the body needs cholesterol to function and it occurs naturally in every cell of the body, too much cholesterol can build up in the coronary arteries and increase the risk of heart disease. It is the low density lipoprotein that carries cholesterol to every cell in the body, for potential use in cell membrane or for other uses example assisting the body to make certain hormones, make up digesting bile acids in the intestine etc. the cells take only what they need, so high level of low lipoprotein can result in deposits of excess cholesterol in the arteries causing restricted blood flow. Eventually, a blood clot may block a narrow artery and result in a heart attack or stroke. 


\section{NUTRITIONAL BENEFITS OF TIGERNUT}

The high content of Oleic acid in the tigernut has positive effect on cholesterol thereby preventing heart attacks, thrombosis and activates blood content of soluble glucose. Cyperus esculentus (Tigernut) reduces the risk of colon cancer. It prevents constipation. Tigernut contains a good quality of vitamin $B_{1}$ which assists in balancing the central nervous system and helps to encourage the body to adapt to stress. The milk supplies the body with enough quantity of Vitamin $\mathrm{E}$ essential for fertility in both men and women.

\section{MEDICINAL VALUE AND USES OF CYPERUS ESCULENTES (TIGERNUT)}

Tiger nut have high nutritional value, high caloric and moderate protein levels. This has called attention to its ability to replace less nutritious food source among populations that face malnutrition especially Africa, India, etc. and other countries with high populations. It is known to contain high level of starch more than potatoes, high fat content (30\%), and good fiber content, rich calcium, iron, phosphates, nitrates and a good additional source of protein. Tiger nut also contains magnesium which helps to promote normal muscles and nerve functions to keep the heart beat steady, support immune functions strengthen bones and keep blood pressure at healthy levels and process proteins.

Added to the above nutrition benefits of tiger nut are the medicinal values for instance, it contains high amino acids especially arginine which is a precursor to nitric oxide which helps keep blood vessels wide enough to keep blood flow normal and thus help control blood pressure. Tiger nuts helps to cure erectile dysfunction, protect the body from cardiovascular disease, may prevent heart attacks, thrombosis, activate blood circulation, gives potassium boost (Bamgbose et al, 2003) and the milk can be used as alternative to cow milk as it is lactose free and can be used by individuals uncomfortable with lactose in cow milk (Akoma et al, 2000).

\section{MATERIALS AND METHODS:}

\section{Subjects:}

This consists of 26 persons screened and confirmed with biochemical analysis that they have high level of cholesterol (450-520 mg/dl) present in their blood stream. They were in the age range of 40-56yrs and body weight of $75-82 \mathrm{~kg}$. the control subjects were apparently healthy male subjects.

\section{PREPARATION OF TIGERNUT:}

$2 \mathrm{~kg}$ of Cyperus esculentus (Tiger nut) were weighed and washed several times with clean tap water. They were distributed to the control and test subjects to eat $5 \mathrm{~g}$ daily for 2 weeks ( 14 days).

\section{TOXICITY STUDIES:}

The $L D_{50}$ of the extract of tiger nut in mice was determined using Lorke's method (1983). Mice (60-80g) were fasted overnight for $22 \mathrm{hrs}$ and doses of the extract of tiger nut $(10 \mathrm{mg})$ was administered intraperitoneally to the groups of the mice $(n=3)$ and observed for $24-48 \mathrm{hrs}$. When no death occurred, subsequent doses (15mg/kg body weight) were administered to fresh groups of mice $(n=3)$ and observed for another 24-48 hrs. The mice that served as control received normal saline only. The $\mathrm{LD}_{50}$ for the extract was calculated by geometric mean of the dose killing none of the three mice in the group and dose killing all the animals in the group.

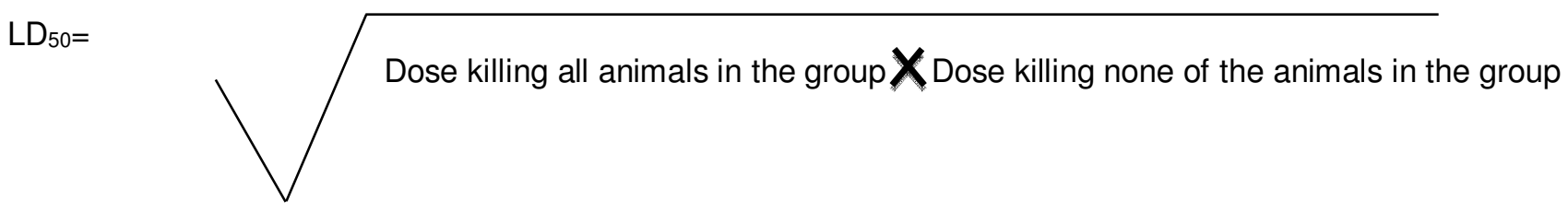




\section{PHYTOCHEMICAL ANALYSIS OF TIGERNUT SEED}

The aqueous extract of the Cyperus esculentus (Tiger nut) was screened for the presence or absence of metabolites using standard phytochemical screening procedures as described by Harbourne (1973), Trease and Evans (1996). The extract was tested for saponins, alkaloids, flavonoids, resins, calcium, reducing sugars, glycosides, carbohydrates, steroids, acidic compounds, fats and oils.

\section{EXPERIMENTAL DESIGN:}

36 subjects were grouped in two groups in this study. 10 persons made up the apparently healthy control group A while 26 subjects made up the test group B. they were given $5 \mathrm{~g}$ of tiger nut daily for 14 days. Their cholesterol level and some haematological profile were analysed pre and post administration of tiger nut.

\section{DETERMINATION OF HAEMATOLOGICAL AND BIOCHEMICAL ANALYSIS:}

Venous blood samples were collected from the cubital vein of the subjects into EDTA sequestrerene bottles and plain bottles for analysis. The biochemical analysis was carried out as described by Baker et al, 1998. The packed cell volume and haemoglobin concentration were determined according to the haematocrit method described by Alexander and Griffiths (1993), white blood cells and platelet count were estimated according to the visual counting method of Dacie and Lewis (1991).

\section{STATISTICAL ANALYSIS:}

The result obtained in this study were represented as mean and standard deviation (Mean \pm S.D), while the students' -t- test was used to compare the result of the control and the test. A P-value of the less than $(P<0.05)$ or equivalent to $(P=0.05)$ was considered statistically significant.

\section{Results}

The results obtained in this study are shown in tables 1-3 and figure 1.

Table 1: The phytochemical analysis of tigernut.

\begin{tabular}{|l|l|l|l|l|l|l|l|l|l|}
\hline & Alkaloids & Tanins & Steroid & Carbohdrate & $\begin{array}{l}\text { Reducin } \\
\text { sugar }\end{array}$ & Calcium & Saponins & Protein & $\begin{array}{l}\text { Resin, } \\
\text { Glycosides, } \\
\text { Flavenoids, } \\
\text { Terpenoids. }\end{array}$ \\
\hline $\begin{array}{l}\text { Degree Of } \\
\text { Concetration }\end{array}$ & - & + & ++ & +++ & + & +++ & - & ++ & - \\
\hline
\end{tabular}

- Negative

+ Present in small concentrations

++ Present in moderate concentrations

+++ Present in high concentrations 
Table 2: Some haematological profile of cholestermic subjects after 14days of tiger nut

\begin{tabular}{|l|l|l|l|l|}
\hline Groups & HB g/100ml \pm S.D & PCV $\% \pm$ S.D & $\begin{array}{l}\text { WBC per } \mathrm{mm}^{3} \pm \\
\text { S.D }\end{array}$ & $\begin{array}{l}\text { Platelet count } \\
\times 10^{9 / \mathrm{L}} \pm \text { S.D }\end{array}$ \\
\hline Control male $\mathrm{n}=10$ & $15.2 \pm 0.6$ & $45.6 \pm 1.8$ & $5,820 \pm 150$ & $241 \pm 37$ \\
\hline $\begin{array}{l}\text { Test subjects before } \\
\text { cyperus esculentus } \\
\mathrm{n}=26\end{array}$ & $15.0 \pm 0.4$ & $45.0 \pm 1.2$ & $6,200 \pm 128$ & $244 \pm 26$ \\
\hline $\begin{array}{l}\text { Test subjects after } \\
\text { cyperus esculentus } \\
\mathrm{n}=26\end{array}$ & $14.7 \pm 0.8$ & $44.1 \pm 2.4$ & $5,640 \pm 138$ & $230 \pm 23$ \\
\hline P Value & $P>0.05$ & $P>0.05$ & $P>0.05$ & $P>0.05$ \\
\hline
\end{tabular}

The result from this table shows that Cyperus esculentus consumption has no adverse effect on some of the haematological profile analyzed in the test subjects. $(P>0.05)$

Table 3: Effects of $c$. esculentus on the biochemical profile of subjects after 14 days of consumption

\begin{tabular}{|l|l|l|l|l|l|l|}
\hline Groups & $\begin{array}{l}\text { Cholesterol } \\
\mathrm{mg} / \mathrm{dl} \pm \mathrm{S} . \mathrm{D}\end{array}$ & $\begin{array}{l}\text { Total Bilirubin } \\
\mathrm{mg} \pm \text { S.D }\end{array}$ & $\begin{array}{l}\text { Conjugated } \\
\text { Bilirubin } \mathrm{mg} / \mathrm{dl}\end{array}$ & $\begin{array}{l}\text { Alk. Phos. } \\
\text { Phatase iu/l }\end{array}$ & $\begin{array}{l}\text { Asp } \\
\text { Transaminase } \\
\text { iu/l }\end{array}$ & $\begin{array}{l}\text { Alanin } \\
\text { Transaminase } \\
\text { iu/l }\end{array}$ \\
\hline $\begin{array}{l}\text { Control male } \\
\mathrm{n}=10\end{array}$ & $180 \pm 20$ & $0.2 \pm 0.05$ & $0.4 \pm 0.1$ & $5.9 \pm 1.2$ & $8.0 \pm 0.4$ & $9.2 \pm 0.3$ \\
\hline $\begin{array}{l}\text { Test subjects } \\
\text { before } c . \\
\text { esculentus } \mathrm{n}= \\
26\end{array}$ & $480 \pm 55$ & $0.3 \pm 0.05$ & $0.8 \pm 0.03$ & $62.0 \pm 1.6$ & $8.3 \pm 0.2$ & $9.0 \pm 0.4$ \\
$\begin{array}{l}\text { Test subjects } \\
\text { after } c . \\
\text { esculentus } \\
\mathrm{n}=26\end{array}$ & $168 \pm 36$ & $0.2 \pm 0.05$ & $0.5 \pm 0.03$ & $51.0 \pm 0.7$ & $7.2 \pm 0.2$ & $8.0 \pm 0.2$ \\
\hline \begin{tabular}{l}
$\mathrm{P}$ Value \\
\hline
\end{tabular} & $\mathrm{P}<0.05$ & $\mathrm{P}>0.05$ & $\mathrm{P}>0.05$ & $\mathrm{P}>0.05$ & $\mathrm{P}>0.05$ & $\mathrm{P}>0.05$ \\
\hline
\end{tabular}




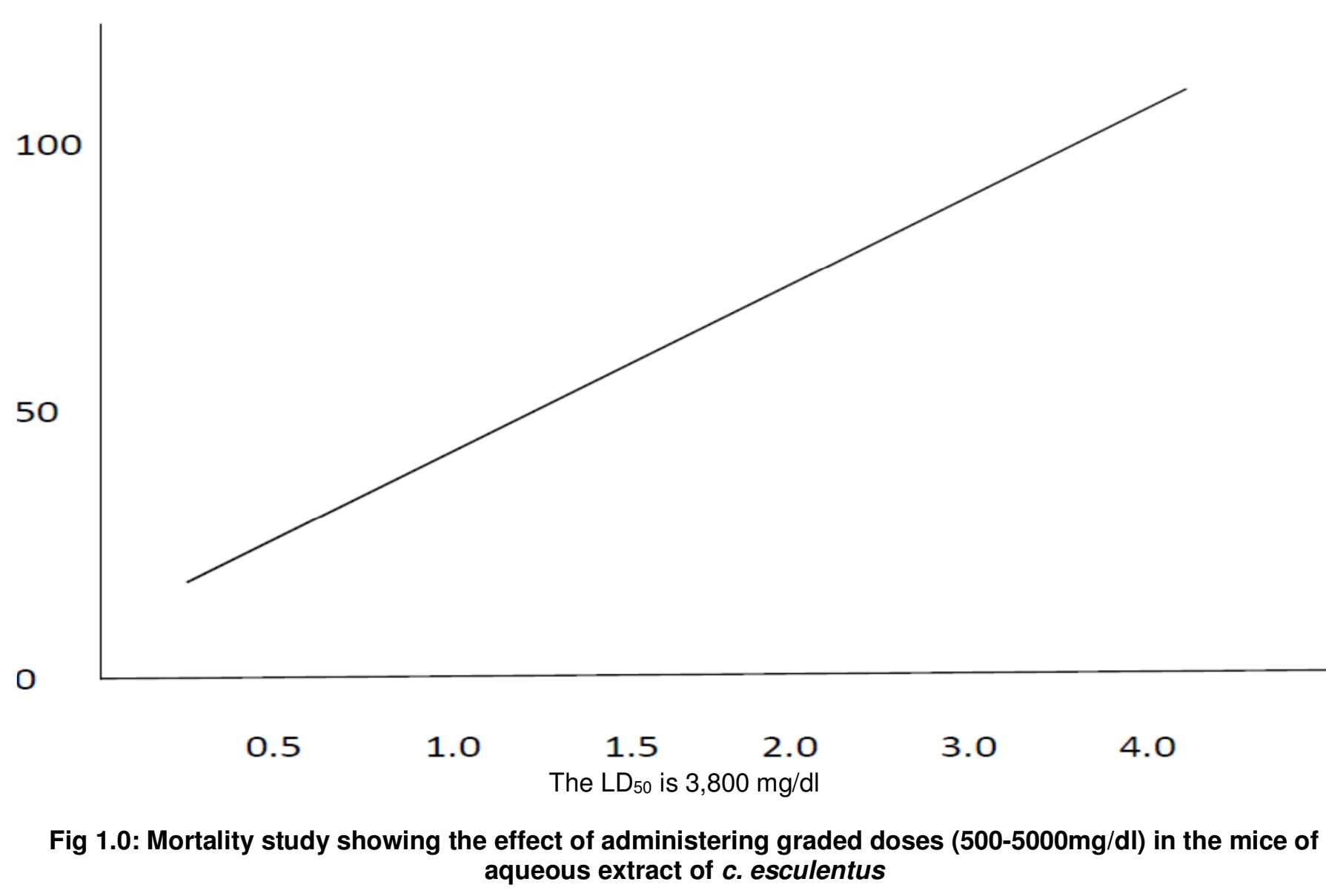

\section{DISCUSSION}

The effect of c.esculentus (Tiger nut) on the haemological and biochemical profile of male cholesteremic subjects in Uli town of Anambra State has been evaluated. The haematological and biochemical analysis provides physiological information on some haemotological indices, cholesterol and liver function profiles. This indicates that consumption of tiger nut could help in lowering cholesterol level in subjects at the risk of developing heart disease due to increased level of serum cholesterol (Hu et al, 1999).

The macronutrients (chemical composition) and the micronutrients (Table 1) confers Tiger nut the natural ability to improve health conditions of male hypercholesteremic subjects. Again the high content of Oleic acid present in tiger nut has a negative effect on cholesterol, thereby preventing heart attacks, thrombosis and activates blood content of soluble glucose. Cyperus esculentus contains 'a good quantity of vitamin $\mathrm{B}_{1}$, which assists in balancing the central nervous system and helps to encourage the body to adapt to stress.

The acute toxicity study (LD $\left(D_{50}\right)$ showed that tiger nut extract was non toxic as shown in fig 1. ( $\left(D_{50}\right.$ of 3,800 $\mathrm{mg} / \mathrm{kg}$ ). the dose used in this study (5g daily) was considered safe for use through out the study. The consumption of tiger nut by the subjects showed no adverse effects on the haemoglobin concentration, packed cell volume, platelet count, white blood cell count and the liver function tests. This then present tiger nut as food that can be used to fight agains malnutrition in under developed nations. It contains a high dietary fiber. This fiber contents helps the body by providing simple relief. It also keeps the body fuller, aiding in weight loss and weight maintenance.

\section{REFERECENCES}

Akuoma O, Elekwa U.A, Afodunrinbi A.T and Onyeukwa G.C (2000). Yogurt from coconut and Tiger nut. TJFD Tech. Africa 5:132-134.

Alexander R.R and Griffit J.N (1993). Haematocrit in Basic Biochemical methods $2^{\text {nd }}$ edition. John Willey and sons inc. publications, Newyork Pp 186-187. 
Baker F.J, Silverton R.E, Pallister C.J (1998). Renal function tests. Baker and Silvertons. Introduction to medical Laboratory Technology. Published by Butterworths and Heinenmann, Linacre House, Jordan Hill, Oxford Ox2 8DP p 140-150

Bamgbose A.M, Truvbetine D and Dada W (2003). Utilization of Tiger nut (Cyperus totundus L) meal in the drits for cockerel starters. Biones. Tech 89: 245-248.

Dacie J.K and Lewis S.M (1991). Practical haematology. Published in London. Churchhill Living Stone Pp 186-187

Harbourne J.B.C (1973). Phytochemical method. Chapman and Hall, London p 269.

Hu F.B, Atampfor M.J (1999). Nut consumption and risk of coronary heart disease, a review of epidemologic evidence. Curr. Artheroder Rep 1999, 1204-9 (Pubmed).

Lorke D, 1983: A new approach to practical acute toxicity testing. Arc. Toxicology $54: 275-278$.

Trease G.E and Evans W.C (1996): Textbook of Pharmcognosy, $14^{\text {th }}$ Ed, W.B Saunders, London p11

Cite this Article: Oguwike FN, Eluke BC, Eze RI, Asika CM, Nwosu PN, Nwafor C, Onumonu C (2017). The effects of Cyperus esculentus (Tiger nut) on Haematological and Biochemical Profile of Male Hypercholesteremic Subjects in Uli, Anambra State Nigeria. Greener Journal of Medical Sciences, 7(4): 036-041, http://doi.org/10.15580/GJMS.2017.4.061717075 